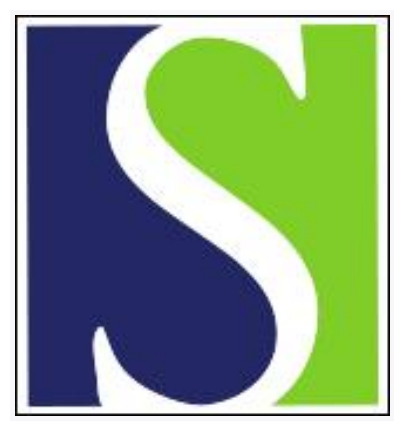

Scand J Work Environ Health 1988;14(5):328-331

https://doi.org/10.5271/sjweh.1911

Issue date: Oct 1988

Oral conditions among workers in the Danish granite industry. by Petersen PE, Henmar P

Affiliation: Institute for Community Dentistry and Graduate Studies, Royal Dental College, Copenhagen, Denmark.

This article in PubMed: www.ncbi.nlm.nih.gov/pubmed/3201194 


\title{
Oral conditions among workers in the Danish granite industry
}

\author{
by Poul Erik Petersen, Dr Odont, Cand Art Soc, ${ }^{1}$ Poul Henmar, DDS ${ }^{2}$
}

\begin{abstract}
PETERSEN PE, HENMAR P. Oral conditions among workers in the Danish granite industry. Scand $J$ Work Environ Health 14 (1988) 328-331. The purpose of the study was to evaluate the oral health situation of workers in the Danish granite industry, in particular, to describe the prevalence and severity of dental abrasion. Measurements of the work environment showed that the workers were exposed to abrasive quartz dust. A total of 39 workers $(72 \%)$ completed a questionnaire on their dental health, work environment, and symptoms from the masticatory system. Only $10 \%$ had been treated by school dental services, and only $51 \%$ made regular visits to the dentist. Consequently, the clinical examinations revealed a high prevalence of dental caries (mean number of decayed, missing, and filled surfaces 87.2 ). The workers' periodontal conditions were poor; the mean percentage of teeth with gingivitis, calculus and pockets deeper than $5 \mathrm{~mm}$ was 13.4 . The prevalence of dental abrasion was $100 \%$; in particular, abrasion was observed on the front teeth. The severity of abrasion and the affection ratio increased by duration of exposure to dust. In conclusion, dental abrasion induced by work-related dust should be considered an occupational disease.
\end{abstract}

Key terms: dental abrasion, industrial dentistry, oral epidemiology, oral occupational disease.

Oral cavity injuries which occur as a direct result of an occupation are rather common. The injurious effect of occupational hazards may manifest themselves in the teeth, jaw bones, periodontal tissues, tongue, lips, and oral mucosa. The effects of the various etiologic agents responsible for oral occupational disease depend on their specific chemical, physical and bacterial nature, their physical state, and their mode of entry (13). Work in mines $(3,12)$, metal work $(6)$, and work in the chemical industry $(4,8)$ may affect the pattern of disease in the periodontium and the oral mucosa (14). Other studies have shown that work in bakeries (2) and in the candy industry (1) increases the prevalence of dental caries. A recent Danish study among chocolate workers (17) demonstrated an increase in the risk of dental caries and periodontal diseases because of a high level of sugar dust in the work environment. As a consequence of the study, the Danish social authorities now recognize "sugar caries" as an occupational disease $(18,20)$.

Dental abrasion is a condition in which tooth substance is lost by frictional effects other than those associated with mastication. It involves a foreign object or substance repeatedly contacting the teeth. Abrasive components exist in several work environments. The purpose of the present study was to evaluate the oral health situation of workers in the Danish granite industry, in particular, to describe the prevalence and

\footnotetext{
1 Institute for Community Dentistry and Graduate Studies, Royal Dental College, Copenhagen, Denmark.

2 General dental practice, Rönne, Denmark.
}

Reprint requests to: Dr PE Petersen, Institute for Community Dentistry and Graduate Studies, Royal Dental College, 20 Nörre Alle, DK-2200 Copenhagen N, Denmark. severity of dental abrasion in relation to exposure to quartz dust.

\section{Subjects and methods}

The survey took place in 1986-1987. The iarget group consisted of all workers $(\mathrm{N}=55)$ employed, currently or formerly, in a Danish granite industry (Rönne, Bornholm). The study population comprised 39 male workers with a mean age of 55 (range $28-75$ ) years. This number corresponds to a response rate of $72 \%$. Twenty-five of the workers had been employed for more than 10 years, nine of the workers for $5-10$ years, and five for less than five years. The study was preceded by dust measurements performed by the Labor Inspection Service. At the time of the investigation the concentration of quartz (abrasive dust) at the crushing mill varied from 2.24 to $2.38 \mathrm{mg} / \mathrm{m}^{3}$.

A questionnaire was used to collect data on residence, education, work conditions, dental health behavior, self-assessment of dental health status, and symptoms from the temporomandibular joints and muscles. Information about oral health status was based on clinical observations. Dental caries and removable dentures were recorded as described by the World Health Organization (21). The assessment of periodontal status was based on the Periodontal Treatment Need System $(10,15)$. The periodontal registrations included all teeth present. The dental abrasion of each tooth was recorded according to recommended criteria (21). The following coding was used: $0=$ no abrasion, $1=$ abrasion of the enamel - cusp still visible, 2 = dentine exposed, $3=$ occlusal relief worn away leaving a peripheral rim of enamel, and $4=$ crown worn down close to the cementoenamel junction. Finally, 
the presence or absence of pain or tenderness from the temporal and masseter muscles was recorded according to the results of a palpation test (5), and the worker's capacity to open his mouth was measured in millimeters.

Data analysis. Caries experience was described by the DMF-S index, ie, the number of decayed (D), missing due to caries (M), and filled (F) tooth surfaces $(S)$. The periodontal status was expressed by the following variables: (i) the percentage of present teeth with healthy periodontium (0), (ii) the percentage of teeth with gingivitis without calculus (A), (iii) the percentage of teeth with gingivitis and calculus (B), (iv) the percentage of teeth with gingivitis, calculus, and pockets deeper than $5 \mathrm{~mm}(\mathrm{C})$, and $(\mathrm{v})$ the percentage of teeth with gingivitis, calculus, pockets deeper than $5 \mathrm{~mm}$, and looseness of the third degree (D). The means were computed for the caries experience and periodontal variables. For the description of dental abrasion, the number of teeth with various affections was calculated, and the means were computed.

\section{Results}

Work conditions. Most of the workers had had seven years of schooling. Half of them were unskilled workers, one-fourth were semi-skilled, and one-fourth were skilled. Shift work was reported by $15 \%$. Various disturbing or embarrassing work conditions were reported frequently (table 1). The respondents claimed the use of protective equipment as follows: ear protector (77 \%), eye protector $(64 \%)$, skullguard $(59 \%)$, gloves $(56 \%)$, and face guard $(26 \%)$.

Dental health. Only $10 \%$ of the respondents had been treated by school dental services, and only $51 \%$ visited the dentist regularly. While $70 \%$ of the participants claimed to brush their teeth twice a day or more, only $5 \%$ reported daily toothbrushing at work. A total of six persons were edentulous and had dentures in both jaws; six persons had a denture for the maxilla only; and three persons had a denture for the mandible only. Among the dentate respondents, one-tenth claimed to have teeth in good condition, while $84 \%$ declared that their teeth were bad or fairly good. Healthy gingival conditions were reported by one-fourth, and two-thirds reported bad or fairly good gingival conditions. Sixty percent answered that they were in need of dental treatment. One-third claimed to have had a great deal of trouble in their lifetime with their teeth or gums, and these problems were related to the work environment. The results of the questions on function of the masticatory system are shown in table 2 . Headache (daily/ weekly) was claimed by $18 \%$, and $15 \%$ reported using analgesics against headache or facial pain daily or weekly.

Among the dentate granite workers the mean caries index was as follows: $\mathrm{D}-\mathrm{S}=4.5, \mathrm{M}-\mathrm{S}=65.7, \mathrm{~F}-\mathrm{S}=$
11.9, and DMF-S $=82.1$. The number of untreated dental caries among the 28- to 54-year-olds was high (D-S $=8.0$ ). The total caries index increased to 87.2 when the edentulous persons were included. The mean number of teeth present varied from 23.1 among the 28 - to 54-year-olds to 12.0 among the 55- to 75 -yearolds. The mean percentage of teeth with a healthy periodontium was 6.8 , the percentage of teeth with gingivitis without calculus was 48.3 , the percentage of teeth with gingivitis and calculus was 31.5 , while the percentage of teeth with pockets deeper than $5 \mathrm{~mm}$ or looseness of the third degree was 13.4. The clinical examinations revealed that no workers suffered from muscle symptoms and that the mean size of the mouth opening was $46.5 \mathrm{~mm}$.

Abrasion. All the dentate workers were affected by dental abrasion. As shown in table 3 and illustrated in figure 1, abrasion was frequent on the front teeth (incisors, cuspids). A severe pattern of abrasion was observed for workers with exposure to dust for 10 years or more. Furthermore, the affection ratio (number of teeth with abrasion/number of teeth present) increased as the duration of exposure increased (table 4).

\section{Discussion}

In Denmark, the granite industry is only found on the island of Bornholm. However, the dental health problems in terms of abrasion may also occur in comparable industries. For example, stone cutters, sand blowers, and construction workers should be consid-

Table 1. Percentage of workers who reported having been exposed to various work conditions $(N=39)$.

\begin{tabular}{lc}
\hline Work condition & Percent \\
\hline Temperature excessively warm & 31 \\
Temperature excessively cold & 74 \\
Excessive changes in temperature & 59 \\
Draft & 74 \\
Humidity & 59 \\
Dirtiness & 82 \\
Dust & 92 \\
Unpleasant smell & 21 \\
Smoke & 15 \\
Mess and litter & 41 \\
Stress from the lifting of heavy weights & 85 \\
Vibration & 82 \\
Stress from pushing or thrusting movements & 87 \\
High noise level & 85 \\
\hline
\end{tabular}

Table 2. The percentage of respondents with symptoms (daily) from the masticatory system $(N=39)$.

\begin{tabular}{lr}
\hline Symptom & Percent \\
\hline Pain & 5 \\
Clicking or grating in jaw joint & 8 \\
Tenderness of teeth & 10 \\
Tenderness/fatigue in cheeks & 3 \\
Difficulties in opening mouth & 8 \\
Locking of jaw & - \\
Grinding of teeth & 5 \\
\hline
\end{tabular}


Table 3. Mean number of teeth with abrasion at different levels in relation to tooth type and age.

\begin{tabular}{|c|c|c|c|c|c|c|c|c|c|c|c|c|c|c|c|c|}
\hline \multirow{3}{*}{$\begin{array}{l}\text { Age group } \\
\text { (years) }\end{array}$} & \multicolumn{16}{|c|}{ Tooth type } \\
\hline & \multicolumn{4}{|c|}{ Incisors } & \multicolumn{4}{|c|}{ Cuspids } & \multicolumn{4}{|c|}{ Premolars } & \multicolumn{4}{|c|}{ Molars } \\
\hline & 1 & 2 & 3 & 4 & 1 & 2 & 3 & 4 & 1 & 2 & 3 & 4 & 1 & 2 & 3 & 4 \\
\hline $\begin{array}{ll}28-54 & (\mathrm{~N}=15) \\
55-75 & (\mathrm{~N}=18)\end{array}$ & $\begin{array}{l}1.2 \\
0.8\end{array}$ & $\begin{array}{l}3.9 \\
2.5\end{array}$ & $\begin{array}{l}0.4 \\
1.0\end{array}$ & $\overline{0.5}$ & $\begin{array}{l}0.4 \\
0.4\end{array}$ & $\begin{array}{l}1.9 \\
1.5\end{array}$ & $\begin{array}{l}0.4 \\
0.9\end{array}$ & $\overline{0.3}$ & $\begin{array}{l}0.9 \\
1.1\end{array}$ & $\begin{array}{l}2.1 \\
1.0\end{array}$ & $\begin{array}{l}0.3 \\
0.6\end{array}$ & $\begin{array}{l}0.1 \\
0.1\end{array}$ & $\begin{array}{l}1.3 \\
1.0\end{array}$ & $\begin{array}{l}0.6 \\
1.0\end{array}$ & $\begin{array}{l}0.4 \\
0.1\end{array}$ & $\overline{0.2}$ \\
\hline
\end{tabular}

a 1 = abrasion of the enamel - cusp still visible, $2=$ dentine exposed, 3 =occlusal relief worn away leaving a peripheral rim of enamel, and $4=$ crown worn down close to the cementoenamel junction.

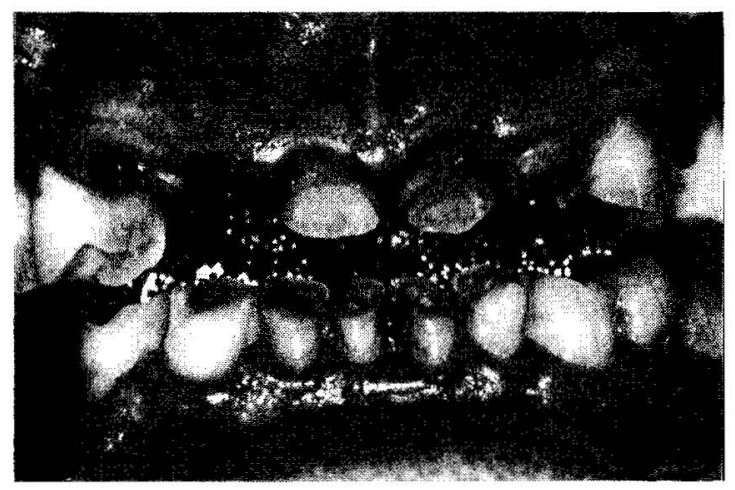

Figure 1. Dental abrasion in a 64-year-old granite worker.

Table 4. Mean number of teeth with abrasion of different levels and the affection ratio in relation to duration of exposure.

\begin{tabular}{|c|c|c|c|c|c|c|}
\hline \multirow{2}{*}{$\begin{array}{l}\text { Duration } \\
\text { of exposure }\end{array}$} & \multicolumn{4}{|c|}{ Degree of abrasiona } & \multirow{2}{*}{$\begin{array}{l}\text { Total } \\
\text { number of } \\
\text { affected } \\
\text { teeth }\end{array}$} & \multirow{2}{*}{$\begin{array}{l}\text { Affection } \\
\text { ratio }\end{array}$} \\
\hline & 1 & 2 & 3 & 4 & & \\
\hline $\begin{array}{l}<10 \text { years }(N=14) \\
\geq 10 \text { years }(N=19)\end{array}$ & $\begin{array}{l}3.8 \\
3.3\end{array}$ & $\begin{array}{l}8.5 \\
6.0\end{array}$ & $\begin{array}{l}1.5 \\
2.6\end{array}$ & $\begin{array}{l}0.1 \\
1.1\end{array}$ & $\begin{array}{l}13.9 \\
13.0\end{array}$ & $\begin{array}{l}0.64 \\
0.87\end{array}$ \\
\hline
\end{tabular}

ered risk groups. This survey comprised both active workers and pensioners and an acceptable response rate was obtained. In comparison to similar studies of industrial workers $(15,16)$, our investigation showed that granite workers had rather poor dental conditions. However, this finding was explained by the more irregular dental care habits since only a few persons had been treated by school dental services and a low proportion of the workers made regular visits to the dentist in adult life. The survey also showed that most of the granite workers were aware of their poor dental health status, and many related their dental problems to the work environment. Poor work conditions, including exposure to dust, were reported. The concentration of quartz dust was considerably higher than the concentration recommended as a maximum for industrial hygiene in Denmark $\left(0.1 \mathrm{mg} / \mathrm{m}^{3}\right)$.

In general populations, extremely worn dentitions are uncommon. Loss of tooth structure due to causes other than dental caries may be associated with physiological and/or pathological processes, usually classified as being the result of erosion, attrition, or abrasion. Dental erosion is defined as the loss of tooth substance by a simple chemical process and is frequently the result of exposure to acids. Industrial environmental factors have been reported to cause dental erosion (19). Attrition refers to the physiological wearing away of tooth substance as a result of toothto-tooth contact. Grinding and/or clenching of teeth due to hyperactivity in the masticatory muscles are considered to be necessary for the development of pathological attrition.

In the present study attrition may be excluded as an explanation of dental wear since only a few participants reported symptoms from the masticatory system. The level of reported symptoms corresponds to similar Danish findings (11). Furthermore, the findings on selfreported disorders of the masticatory system were supported by the clinical observations. In accordance with previous reports $(7,9)$ the observed dental wear among the granite workers should therefore be ascribed to the abrasive components of the work environment. This phenomenon was also demonstrated by the dose-effect relationship (table 4).

First of all, dental abrasion among granite workers and similar occupational groups ought to be prevented through the reduction of the dust level. However, until such a reduction is achieved, the use of face guards and regular toothbrushing at work should be recommended. In cases of extremely worn dentitions dental reconstruction is not only a difficult clinical problem but also very expensive, due to the fact that complicated treatments (crowns, bridges, etc) are not covered by the National Health Insurance. Since this type of severe dental abrasion is closely related to the work environment, the lesion should be considered an occupational disease. Consequently, dental abrasion ought to be entitled to compensation in Denmark according to the Industrial Injuries Insurance Act.

\section{References}

1. Anaise JZ. Prevalence of dental caries among workers in the sweets industry in Israel. Community Dent Oral Epidemiol 6 (1978) 286-289.

2. Anderson T, Larsson PG. Kariesutbredningen hos bakere och konditorer i Malmö [Caries experience among bakers and pastry cooks in Malmö]. Odontol 
Revy 18 (1967) 303-307.

3. Bieda J, Gawrzewska B, Kaczmarczyk-Stachowska A, Knychalska-Karwar Z, Lashowska L, Pelc M, Szafraniec 1 , Wedler $A$. The incidence of parodontopathies in salt mineworkers in Wieliczka. Czas Stomatol 21 (1968) $1271-1275$.

4. Domzalska E, Grabowska K, Kamocka D. The influence of chemical factors on the oral cavity in workers of the Szcecin Plant of Phosphorus Fertilizers in the light of own investigations. Czas Stomatol 21 (1968) 1081-1087.

5. Duinkerke ASH, Luteijn F, Bouman TK, de Jong HP. Reproducibility of a population test for the stomatognatic system. Community Dent Oral Epiderniol 14 (1986) $80-85$.

6. Dunska E, Kaczmarczyk-Stackowska A, ProstakKosowska K, Slowik T, Zabicki J. Serum ascorbic acid level in patients with parodontopathies working in the Coke-Chemical plant of Lenin Steel Works. Czas Stomatol 26 (1973) 441—443.

7. Enbom L, Magnusson T, Wall G. Occlusal wear in miners. Swed Dent J 10 (1986) 165-170.

8. Florescu M. Dental lesion in workers from the sulforic acid industry. Stomatologiia (Mosk) 19 (1972) 392-403.

9. Frykholm KO. Undersökning av tandförhållanden hos järnverksarbetare inom ett sinterverk med särskild hensyn till abrasionsskador [Investigation of occlusal wear in workers in the sintering plant of an ironwork]. Odontol Tidskr 71 (1963) 199-211.

10. Johansen JR, Gjermo P, Bellini HT. A system to classify the need for periodontal treatment. Acta Odontol Scand 31 (1973) 297-305.

11. Kirkegaard E, Borgnakke WS, Groenbaek L. Oral health status, dental treatment need, and dental care habits in a representative sample of the adult Danish population. Royal Dental College, Copenhagen and Aarhus 1986. (Thesis).

12. Knychalska-Karwan Z, Bildowa J, Gawrzewska B, Kaczmarczyk-Stakowska A, Lashowska L, Pelc M, Szafra- niec I, Wedler A. State of dentition of workers of the salt mines in Wieliczka. Czas Stomatol 26 (1973) $1291-1295$

13. Lammert KH, Seifert H. Stomatologie und Arbeitsmedizin. VEB Verlag Volk und Gesundheit, Berlin 1979.

14. Larsen VK. Praevalensen af mundslimhindelidelser hos 1075 grafiske arbejdere [Prevalence of oral mucosal lesions among graphic workers]. Royal Dental College, Copenhagen 1981. (Thesis).

15. Petersen PE. Dental health behaviour, dental health status, and dental treatment needs among workers and staff-members of a Danish shipyard: A socio-dental industrial investigation. Odense University, Odense 1981. (Doctoral dissertation).

16. Petersen PE. Dental visits, dental health status and need for dental treatment in a Danish industrial population. Scand J Soc Med 11 (1983) 59-64.

17. Petersen PE. Dental health among workers at a Danish chocolate factory. Community Dent Oral Epidemiol 11 (1983) 337-341.

18. Petersen PE. Erhvervssygdomme og loven om arbejdsskadeforsikring [Occupational diseases and the Industrial Injuries Insurance Act]. Tandlaegebladet 91 (1987) 91-94.

19. Sandin G. Dental health among workers at three acid producing factories. University of Lund, Lund 1983 (Doctoral dissertation).

20. Sikringsstyrelsen. Bekendtgörelse om fortegnelse over erhvervssygdomme i medför af lovgivning om arbejdsskadeforsikring [List of occupational diseases according to the Industrial Injuries Insurance Act]. Copenhagen 1986.

21. World Health Organization. A guide to oral health epidemiological investigations. Geneva 1979.

Received for publication: 29 April 1988 